\title{
9 Between environmental subsystem change and extractive regime resilience
}

\author{
Beyond the apparent development of \\ Chilean environmental institutions \\ (1990-2019)
}

Antoine Maillet ${ }^{1}$ and Sebastián Carrasco

\section{Introduction}

Chile is not a typical case of resource curse. Since the Pinochet dictatorship ended, it has been praised for the quality of its institutions, particularly by investors (World Bank Group, 2019). Some even argue that it managed to overcome the curse (Haslam, 2016). However, these optimistic views have been confronted by critics of the growth-oriented model, who have increasingly mobilized against extractive projects since the end of the 1990s (Delamaza et al., 2017). The opposition towards particular projects had cumulative effects that led to larger critique of the environmental policy and can be linked to policy change at the end of the 2010s (Sepúlveda \& Villarroel, 2012). At the same time, this emerging environmental critical discourse and its consequences for policy implementation were met by growing discontent by the private sector, which began to see it as an obstacle to its own interests that they framed as national interests.

The commodity boom took place in this setting where neither the private sector nor environmentalists had a positive appraisal of Chilean environmental institutions that have deemed variously as market-conforming (Tecklin et al., 2011) or anti-private sector (Lira, 2017). This debate also frames our approach to the questions of this book. To answer the question of whether institutions that were developed and implemented did foster a greater distribution of the extractive sector's gains and a stronger reduction of the extractive sector's costs, we have to establish whether environmental institutions have obstructed or hindered extractive projects. To do so, we need a theoretical framework that will allow us to tackle institution-building and institutional change, going beyond formal modifications that might mask the continuity of inadequacies. In short, our main argument is that the different transformations of environmental institutions in Chile turn out to be rather marginal modifications that, despite advancing in certain aspects, do not change the policy regime. 
The structure of this chapter is as follows. In the first place, we elaborate a theoretical framework based in the literature about policy change, especially in environmental politics. Then, we propose a narrative of the institutional path of environmental institutions in Chile and the determinants of their change, arguing that these transformations are only apparent. Later, we confront the narrative of an institutional path with the data on expenditure in environmental protection and investment in mining projects. This section shows that Chilean institutions have neither slowed down nor accelerated the dynamics of the commodity boom, and that the dynamic of change in the environmental subsystem is nested in a largely unchanged extractive regime. Finally, some conclusions are provided that contribute to a better understanding of the dynamics of environmental policies in Chile.

This chapter is based on a large literature review about Chilean environmental policy since the 1990s, several case studies about specific laws or conflicts, and interviews with policymakers, private sector officials, environmentalists and academic experts. For the case studies, newspapers and other media (particularly from Diario Financiero) and the story of law (historia de la ley) that the Chilean Congress publishes were valuable sources. Other government documents were also analyzed, such as reports that evaluate and analyze the implementation of environmental assessment instruments. Finally, we also used a database delivered by the Environmental Assessment Service (SEA), to analyze the evolution of mining projects in the country.

\section{Path dependence, tensions and apparent policy change in environmental policy}

The hallmark of historical institutionalism is the concept of path dependence (Mahoney, 2000). Its construction has been a major breakthrough in neo-institutionalist studies, as it has allowed to envision institutional processes as deeply structured by the past and perpetuated by the increasing returns the institutions produce (Pierson, 2004). However, it would be misleading to take it as negation of a possibility of change, as a concomitant literature on policy change has made clear. Instead, the observation of path dependence has motivated further developments in conceptualizing forms of change, building on incrementalism to create alternative categories to replacement such as layering, conversion or drift (Mahoney \& Thelen, 2010; Streeck \& Thelen, 2005). Other authors have observed "hybridization" (Maillet \& Rozas Bugueño, 2019).

Layering in particular has been fruitfully used for environmental policy analysis in the case of Peru, where a process described as fragmented layering has happened (Orihuela \& Paredes, 2017). Change came the form of new layers growing on formal environmental institutions that remained fragmented among various public organizations.

More important than what this process tells us about Peru's environmental trajectory is the general finding that formal and procedural changes such as institution-building do not necessarily mean that there is a substantial policy 
change. Since apparent change is relatively frequent, the literature has distinguished between adaptive and transformative change, based in the observation of neoliberal resilience (Madariaga, 2016). Opponents of change who face external pressure may embrace or even propose (apparent) changes in order to preserve their dominant position.

Understanding the concepts of policy subsystem and policy regime helps understand this difference. Our hypothesis is that apparent change is the outcome of a process of change in the subsystem level, and resilience in the regime. By switching from a subsystem to a regime perspective, we are better equipped to analyze the power issues at stake. Regime has been proposed in policy and governance analysis as a way to study the governing arrangements that tackle issues that span beyond subsystem boundaries (Jochim \& May, 2010) or "dispersed problems that lack comprehensive efforts to address them" (May \& Jochim, 2013). A regime is characterized by a set of ideas, governing arrangements and interests of stakeholders (ibid.). Regime analysis tends to address the level of problems, ideas, institutions and actors, while subsystem analysis tends to focus instead on the formal institutions.

While regimes and subsystems often are analyzed at the national level, multilevel analysis is particularly suited for environmental issues. They are sometimes even framed strictly as global issues, with a focus on "world-level organizations, understandings, and assumptions that specify the relationship of human society to nature" (Meyer et al., 1997). They can also be looked at from a local point of view where the focus is put on restricted areas, where environmental damages and suffering are localized (Delamaza et al., 2017). However, instead of exclusionary positions, the literature has mainly adopted an interconnected perspective, manifest in the expression of glocalization, that can be applied for example to issues such as mining conflicts (Paredes, 2016).

Processes related to environmental public policies in particular cannot be reduced to either an isolated top-down or bottom-up succession of events, but have to be considered in their transnational aspects (Orihuela, 2014). Nevertheless, the national level remains prominent because that is where environmental rules, standards or organizations can be observed when they are built. In that case, the typical entry from a policy study perspective builds on a subsystem approach to public policy: "Policy subsystems are semi-autonomous subsets of a political system with particularized policies, processes, and politics tailored to their issues" (Heikkila et al., 2018). The creation of new organizations to deal with emerging issues, such as agencies or ministries, usually takes place within a tension between on the one side the urge for looking at the intersectoral or trans-sectoral ${ }^{2}$ dimensions of a problem, and on the other the specific logic of sectorization, which operates in such a way that a problem might not be taken seriously until it has its own subsystem (Muller, 2009).

This problem of the sectoral or intersectoral character of policies has been studied for topics such as gender or ethnic discrimination (Halpern \& Jacquot, 2015; Muller, 2009), but this dilemma is also applicable for 
environmental policies. New organizations have been created around the world, often in charge of intersectoral coordination, but with little power to do so. In fact, they have dealt with a sectorization trap: confining the environmental problem in a subsystem where the transversal dimension is lost, or at least passes into the background. This whole process can also be read in terms of power. As Pierson showed, power gets built in institutions (Pierson, 2015). Having a ministry - the formal component of a subsystem-does not resolve the power issues. On the contrary, it might well hide it, for some time at least, below the symbolic gain produced by the formal creation of a new institution such as the environmental ministry. So, there might be change, but it might be only apparent.

To go beyond apparent change and grasp these power issues, we need a concept able to consider the environmental issues as a transversal problem. To do so, the analytical answer lies in the concept of policy regime, an excellent alternative to tackle "boundary-spanning problems" (Jochim \& May, 2010). In short, the main argument of this literature is that even apparently large institutional changes are not necessarily transformative. In the case of environmental policies, this implies that even when there have been changes in formal institutions, in general these are actually only changes in the subsystem, because the regime (as understood by May \& Jochim, 2013) continues to operate with the same set of ideas and interests of actors. More generally, this case adds to the findings regarding the continuity and resilience that neoliberalism has had in Chile after the dictatorship (Madariaga, 2018).

In the case at hand, going back to the problem-based regime analysis has important pay-offs, as it allows us to recast the discussion of the emergence of the limitations of the environmental institutions into a discussion on the resilience of the extractive regime. ${ }^{3}$ In both cases, we deal with the literature on policy change. We should at the same time look at why and how countries follow global trends in how their environmental subsystem plays out, but also how this affects—or not - the more relevant game of the developmental regime; in the case of Chile, an extractive one.

\section{Apparent change: the trajectory and determinants of Chilean ecological modernization}

During the Pinochet dictatorship, the environment received scarce attention (Silva, 1996). With the return to democracy came a big push for environmental protection, which generated two waves of ecological modernization (CamposMedina, 2019). The first one led to the Law 19300 of the environment, which created the National Corporation of Environment (CONAMA) and the Environmental Impact Evaluation System (SEIA) in 1994, and the second to the creation of the Environment Ministry, the Superintendence of Environmental and environmental courts through several laws between 2010 and 2012. The design and implementation of these formal institutions are the product of the tension between processes at the subsystem and regime levels. 


\section{Foundation of the environmental system: the creation of CONAMA and the system of environmental impact}

In 1992, President Patricio Aylwin sent a bill to create a new formal environmental institution that was approved in 1994, a few days before he left office. The newly created CONAMA — which ranked lower than ministries-was charged with the task of defining environmental policy (Carruthers, 2001) and advocating for environmental issues in sectoral ministries (Barandiaran, 2016). The SEIA began to operate only three years later, after the implementing regulations (reglamento) of the law finally passed.

Contradictory pressures are apparent in the design of this environmental system. The policy subsystem around CONAMA and SEIA was placed at a disadvantage compared to the subsystems that had long been consolidated under the Ministry of the Economy and the Ministry of Public Works. The window of opportunity for advancing in environmental issues was constituted by the postPinochet democratic transition. An emerging ecologist movement participated with the democratic opposition and managed to set the topic in the transition agenda (Silva, 1996). Their cause was aided by the international context with the Río 1992 Summit, where the United Nations Framework Convention on Climate Change was approved. But the international dimension was above all present in Chile's aspiration to become part of North American Free Trade Agreement (NAFTA), which imposed environmental requirements as a condition for membership. These international pressures for environmental policy change were coming at the beginning of Chile's strategy of international integration that the country pursues until today, in which environmental protection is merely instrumental. The lower priority on the substance of environmental policy as opposed to its optics also helps explain why the new system is part of a compromise between sectoral preoccupation and deeper regime orientations, which could share a short-time goal but not the same vision or goals. Indeed, the main objective of President Aylwin was economic growth (Silva, 1996), above environment, as he made clear in a speech he gave in 1992:

Environmental conservation cannot be considered in a restrictive meaning. Our country requires to satisfy growing needs in housing, health, education, energy, etc. This involves putting to work the resources that it counts on. Environmental protection cannot be considered in a trade-off with development, but as one of its components.

(Aylwin, 1992, pp. 6-7, cited in Campos-Medina \& Larenas, 2012, translation by the authors)

The priorities of the government, together with the drop in social mobilization (Carruthers, 2001), led to a political accommodation, in which civil society demands were incorporated, but with no harm for business groups (Silva, 1996). The concern for the environment had been institutionalized in a subsystem, but subordinated to the imperative of economic development (Tecklin et al., 2011). 
The set of regulations following the first one is a manifestation of institutional development of the subsector. Environmental evaluation and certification of new projects by the state progressively became a more sophisticated administrative process, as showed by Decree 95, which modified the regulation of the SEIA. It established the definitions of protected area, execution of project or activity and modification of project or activity and technical specifications of impact evaluations, such as the formal steps of an evaluation, the components of a report, or the channels to hand information to public authorities. However, these guidelines did not prevent the emergence of new social conflicts over extraction.

\section{Emerging conflicts and a latent institutional crisis}

The general public became quickly aware that the creation of new organizations and the institution of the evaluation process did not solve the environmental problems, as shown by the results of an opinion poll by the Centro de Estudios Públicos in 2000. When asked, "do you think that Chile is doing more than enough, the right effort, or too little", more than $80 \%$ answered "too little" (Centro de Estudios Públicos, 2001). More important that public opinion polls, however, for the re-emergence of the environment on the public agenda was the major negative environmental impacts caused by projects that had successfully passed the evaluation process.

The first important environmental conflict occurred during the Frei presidency, which followed the Aylwin presidency in 1994. The construction of the hydroelectric plant "Ralco" in the Bío-Bío River, which would strongly affect Pehuenches communities, was approved in 1997, even though some of the public authorities had stated their opposition during the evaluation process (Carruthers \& Rodríguez, 2009). The contestation of the project through protests and legal instruments followed until the plant went into operation, in 2004, and even if it did not manage to stop it, it contributed highly to illuminating the issues of ethno-cultural and biodiversity losses, which in turn questioned the extractive orientation of the economic model (Risley, 2015).

However, opinions that criticized the economic model were marginalized by became to be known as the Frei doctrine. ${ }^{4}$ President Frei publicly talked about "balancing the economic growth process of the country with environmental protection" (Frei, 2003) but at the same time promulgated a Presidential Directive that would lead to a pre-approval of all projects in the SEIA (González, 2006). This inclination towards accepting new investments at any cost is well illustrated in other conflicts such as La Farfana or the Black Swans. La Farfana is a water treatment plant in Maipú launched in 2003. The smell it emitted had not been mentioned during the evaluation process. The company was condemned for the damages it caused to more than 400 people (Farías \& Aveggio, 2009).

The Black Swans case that began in 2004 in Valdivia was a tipping point in the local environmental conflicts. The spilling of residues by Forestal Arauco in the Cruces river triggered a dramatic decrease in the swan population from 8,000 to 400 in one year (Sepúlveda \& Villarroel, 2012). The project started 
in 1995 when the Celco-Arauco company sent a proposal to the SEIA. The COREMA (Comisión Regional del Medio Ambiente, responsible for the official environmental review) at first rejected the project, worried by the pollution that could happen in the Cruces River. It was President Frei who put direct political pressure on the COREMA so that they would approve the environmental permits. That is why the mobilization, local, national and international, targeted the environmental institutions as responsible for the situation.

All these cases make clear the tension between a formal environmental subsystem that gave few guarantees for environment and population protection, and a permanent push for more extractive investment. Thus, during this time, the protection of the environment was subject to the regime that was favored by political and economic actors.

\section{Apparent policy change and regime resilience: the second wave of ecological modernization}

In 2010, the most significant change in environment institutions since the $1990 \mathrm{~s}$ occurred with the enactment of Law 20417, which established the Environment Ministry, the Environmental Assessment Service and the Superintendence of the Environment. Two years later, in 2012, Law 20600 establishing the Environmental Courts was enacted. This legislation set up three new courts, distributed geographically in the North, Center and South of the country. These new institutions are the culmination of the redesign of the environmental subsector that began in 2008, when President Bachelet sent the bills that created them to Congress.

In a general view, the transformation of the environmental system responds to a process of incremental change via sedimentation, in which various factors (Orihuela \& Paredes, 2017) and various actors (Madariaga, 2018) have influenced the growth of institutions gradually and differentially.
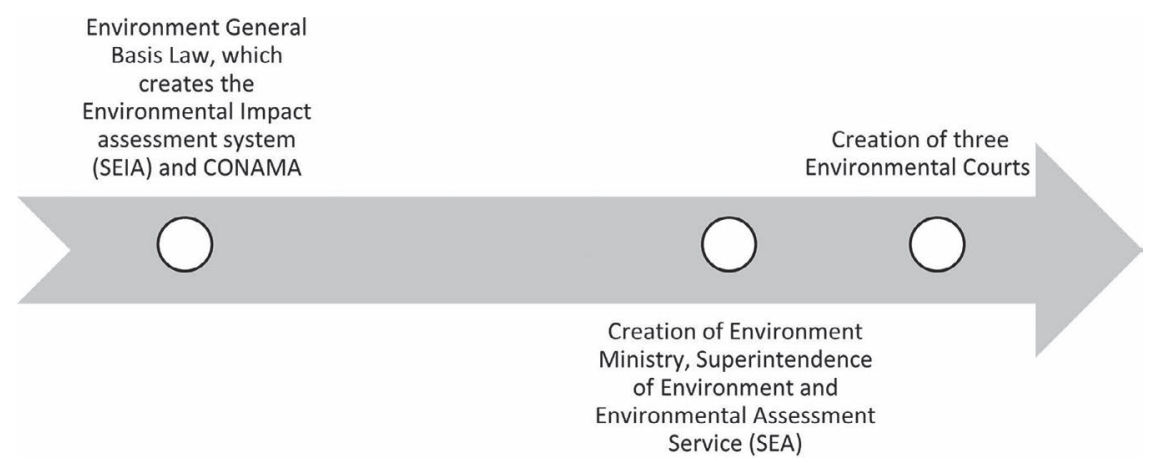

Figure 9.1 Two decades of environmental policy

Source: Own elaboration 
In the first place, the different social movements that began to be articulated since the 1990 s created a transversal support for environmental protection and generated a crisis of legitimacy of the system. This was expressed mainly in a critique of the political role that CONAMA played in the approval of environmentally damaging projects (Barandiaran, 2016).

Secondly, there was also international pressure to generate changes in the system. In the 2000s, the OECD criticized environmental regulations in Chile for their weakness, which constituted a strong external demand to transform the environmental system that existed in the country (Barandiaran, 2016; Tecklin et al., 2011). Specifically, the OECD made recommendations to improve environmental policy, which were a necessary condition for the country to become a member of the organization (Sepúlveda \& Villarroel, 2012).

Thirdly, there are domestic political factors that explain this transformation. In the 2005 presidential elections, very different presidential candidates committed themselves to an institutional change in the environmental field. This concern for the environment was expressed in a transversal way by the different political sectors, which gave an account of the relevance that the subject had acquired. Even Sebastián Piñera, who was the presidential candidate of the political right at that time, made environmental protection one of the main axes of his presidential program (Gamboa \& Segovia, 2006). This way, the environment was established as an electorally relevant issue in domestic politics, which was undoubtedly essential for the subsequent reform of the system (Tecklin et al., 2011). After winning the presidential election, President Michelle Bachelet renewed her commitment to the issue, leading the formulation of the new environmental policy, which ultimately resulted in the establishment of the MMA (the Ministry of Environment), the SMA (the Superintendence of Environment) and the Environmental Courts.

This analysis of formal changes in the environmental subsystem is, however, only one side of the story of Chilean environmental institutions. While these formal changes may be the most visible feature, they did not transform the extractive policy regime that persisted after these reforms.

\section{The persistence of the extractive policy regime}

To illustrate the persistence of the extractive policy regime-as opposed to apparent change in the environmental subsystem - we build on three strands of evidence: aggregated data of extractive projects in Chile, insights from specific conflict cases and budget evidence of the weak position of the environmental institutions in the Chilean state.

\section{Extractive projects in Chile: continuity in the policy regime}

The mining industry has become a key sector for investment of national and transnational capital. Given this, economic elites have developed "a new set of political technologies for expanding extractivism's socio-spatial frontiers" 
(Leiva, 2019, p. 145). In the territories, mining companies have established a capitalist domination at the local level, maintaining support through clientelism (Amengual, 2018) and even defeating the communities that oppose mining projects (Leiva, 2019).

In this section, we present data about the evolution of the mining investment in Chile that allows us to argue about the continuity of the policy regime, despite the apparent institutional changes that developed in the subsystem. We do this analysis in two ways. On the one hand, we observe the decisions taken by the environmental authority regarding the different mining projects. On the other hand, we analyze the investment dynamics to which the sector has been subjected, with special emphasis on the wild fluctuations since the 1990s.

The approval or rejection of investment projects depends on the assessment carried out by the Environmental Assessment Service (SEA). According to the Environment General Basis Law (Law 19300), this assessment "determines whether the environmental impact of an activity or project conforms to current regulations". In general, this tool has two main objectives, one technical and one political. First, it seeks to prevent and/or mitigate the negative externalities of the projects under evaluation. Secondly, the environmental impact assessment intends to limit environmental conflicts, involving citizens in the early stages of the process (Sepúlveda, 2000).

Figure 9.2 show the status of mining projects since the 1990s. As can be seen, only a very marginal percentage have been rejected by environmental regulation (only $4 \%$ ), while the majority of the projects have been approved. Overall, it can be determined that virtually all projects are approved, so the preventive role of environmental assessment is questioned. At the same time, $17 \%$ of the projects have been withdrawn by the project owners. This percentage is consistent with socio-territorial conflicts, where local actors have prevented investment projects to be carried out.

Figure 9.3 shows mining investments in Chile. In the 1990s, the investment of the mining projects amounted to approximately $12,000 \mathrm{MM} \$$. Already in the

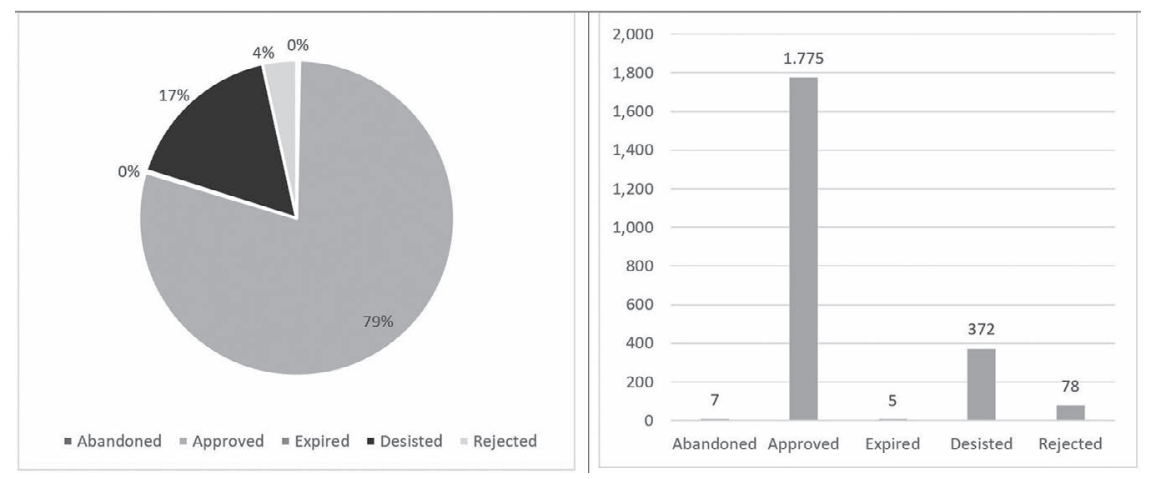

Figure 9.2 Status of mining projects in Chile (1993-2019)

Source: Authors' elaboration based on SEA data 


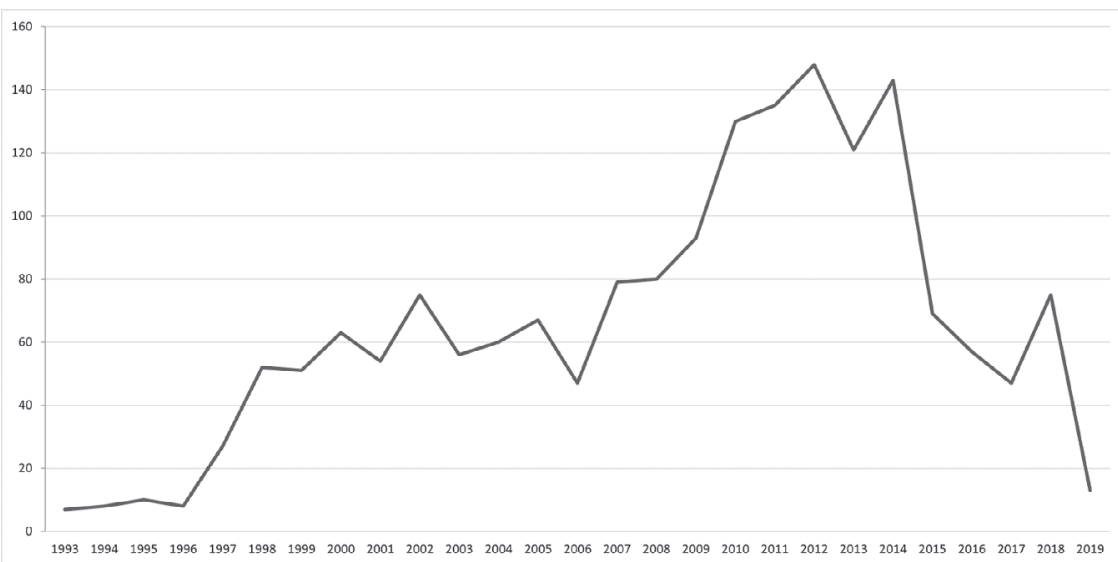

Figure 9.3 Number of mining projects approved by year

Source: Authors' elaboration based on SEA data

2000 s that number increased twice, reaching an amount close to $25,000 \mathrm{MM} \$$. Then that figure continued to increase significantly-reaching more than $35,000 \mathrm{MM} \$$ only between 2010 and 2014 . However, the investment would have a sharp decline from 2014, maintaining a downward trend in recent years. Therefore, the data we present about investment in the mining industry shows that business dynamics have followed cyclical behavior patterns, at least in terms of investment, since the 1990s. In other contexts, changes in environmental institutions have had an impact on investment. In fact, some countries have directly sought to restrict mining activity — as in Ecuador — or even ban it —as in El Salvador (Spalding, 2018). In contrast, in Chile, despite changes in environmental institutions, the industry has followed the dynamics of international economic forces.

As can be seen in Figure 9.3, the number of approved mining projects has gone up and down over the decades, reaching its highest point during the first government of President Sebastián Piñera (Figure 9.4), despite the new environmental institutions having already begun operations. This increase in investment follows the cycles of international commodity prices.

Figure 9.4 illustrates well how the regulations have not reduced investments, despite threats from the industry to respond to new regulations by ending investments. Also, the political authorities have insistently promoted investment, delivering messages to global investors about the legal certainty prevailing in Chile for the development of projects. As an example, in 2013 President Piñera, regarding the Pascua Lama project, pointed out that: "All Canadian investors can be sure that in Chile we have a democratic system and the rule of law is the one who will decide and make the decision on this investment" (EFE, 2013 [translation by the authors]). 


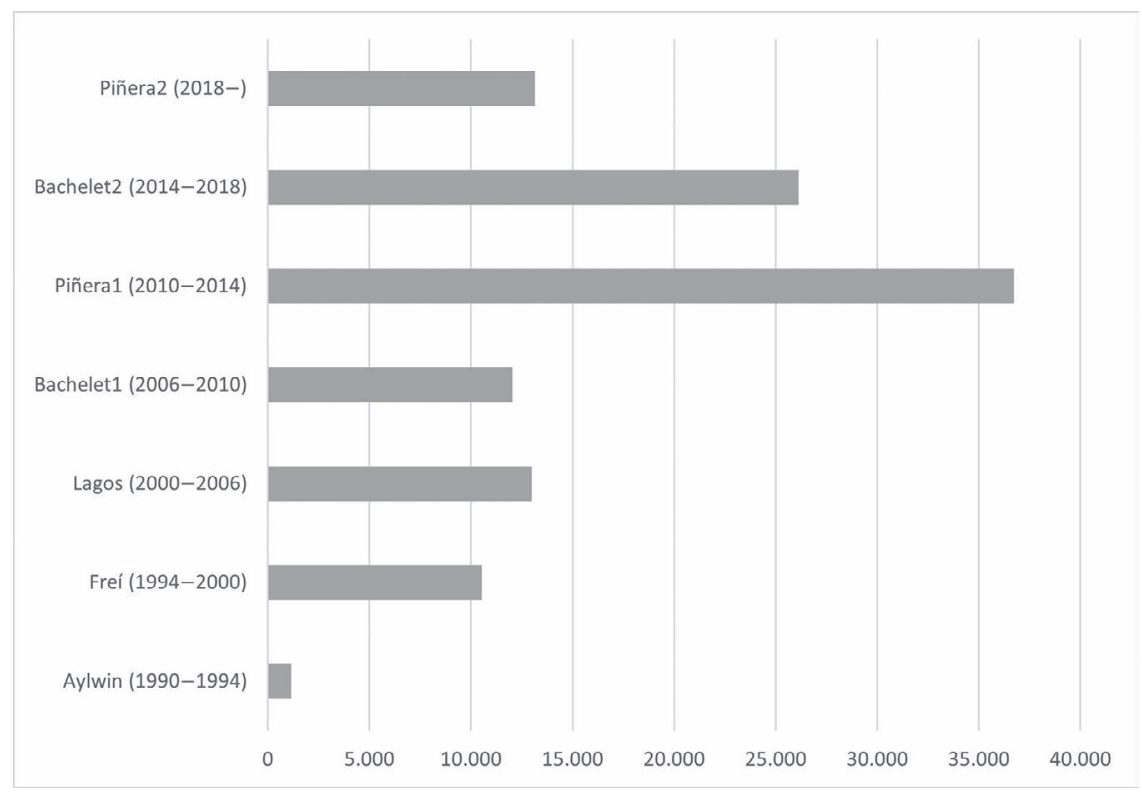

Figure 9.4 Investment amounts mining projects approved according to presidential term (in Chilean MM\$)

Source: Authors' elaboration based on SEA data

In recent years, socio-territorial conflicts have increased progressively in Chile, and conflicts over large-scale mining have come to play a leading role (Delamaza et al., 2017). While some of these conflicts have managed to block certain investment projects, the data presented in this section show that mining investment patterns are driven by extractive dynamics rooted in a context of global capitalism.

Although this chapter does not go deeper into the role of firms, mining firms clearly are using various resources in developing countries to attempt to legitimize themselves in communities (Amengual, 2018). In this sense, Chile has not been the exception (Leiva, 2019). Therefore, this general characterization of mining investment in Chile accounts for two phenomena. In the first place, it points out the approach that the Chilean environmental institutions have taken, by consistently approving mining-based investment projects. Second, it states that investment dynamics respond to exogenous factors rather than to local political and administrative institutions, moving according to international shocks. Business groups as well have generated an active lobby in opposition to state regulations since the return to democracy (Madariaga, 2018). In the case of environmental regulation, despite the opposition of important social movements, in many cases business interests prevailed. Thus, even if there was 
a strong push at the subsystem level, especially with the window of opportunity that the OECD opened, there was also a strong resistance, at the regime level.

Business power in Chile plays a strong role particularly in that it is not only strong in policy changes, but also strong in the implementation phase (Maillet \& Carrasco, 2019). As the establishment of extractive regimes-based on the exploitation of natural resources-generates various conflicting dynamics between the state, communities and companies (Falleti \& Riofrancos, 2018), business groups also manage lobby strategies to reverse the decisions of administrative bodies within the framework of the environmental institutions. For example, some of the few cases where investment projects have been rejected have generated great consternation in the business community. On the subject of a recent case that was rejected by the state, the president of the National Society of Mining stated:

Making investments becomes much more uncertain, because deep down in these projects, as one develops them, spending increases, and when it reaches the moment when the authority has to approve or not approve the resolution of environmental impact, if this is negative, everything that has been advanced is lost. Companies and investors, just to protect the investment they are making, try to do it in the most serious way possible, otherwise it would be a risky attitude.

(Peña \& Vergara, 2017 [translation by the authors])

This quote is typical of the discourse pervasive in business concerning the weight environmental regulation has on their projects, even though our data shows that these regulations are mainly business-friendly.

\section{Environmental policy under pressure: high-profile conflicts versus general trend}

Several high-profile conflicts reveal the ongoing tension between the environmental subsector and the extractive regime in Chile.

Protests over environmental issues intensified under Sebastián Piñera's presidency, as typified by the massive protests against the approval of a mega dam (Hidroaysén) in Chilean Patagonia for the production of hydroelectric energy (Silva, 2016, 2018). The protests began throughout different cities of Chile one day after the project had been approved by the regional COREMA for Coyhaique. Later on, they were articulated in an environmental campaign-Patagonia without Dams - that reached international dimensions and, finally, motivated the Committee of Ministers to reject the project in 2014 (Schaeffer, 2017). In that case, the political dimension of the decision was open, contrary to the alleged technical nature of the decision.

Two cases show that the new environmental institutions remained exposed to political pressure just after being launched. In August 2010, important mobilizations were registered against a thermoelectric project, 
Barrancones, which, if built, would have been located a few kilometers from the Pingüino de Humboldt natural reserve, in the fourth region of the country. The government resolved the case at the time by intervening directly in the process, asking the company for the relocation of the project, even though it had just been approved through the SEIA. The political intervention of the president is an extreme example of political meddling in an environmental institution (Sepúlveda \& Rojas, 2010). Technical and professionalized institutions, decisions remained subject to complex social and political dynamics.

A recent relevant case is the Dominga mining project. On August 21, 2017, the Committee of Ministers, the appeal body of the environmental institutions, rejected the Dominga mining project in the Coquimbo region. The decision was based on insufficient mitigation measures and received votes against the project from the ministers of the Environment, Public Health and Agriculture, while those of Energy and Mining voted in favor and the minister of Economy abstained. The proximity of this initiative to the Humboldt Penguin National Reserve gave rise to serious objections by different environmental groups over many years. In spite of this, the project was supported by the economic ministers, since it meant a strong investment that would bring important economic benefits for the area and the country (Madariaga, 2018). President Michelle Bachelet supported the minister of the Environment, which generated a crisis within the cabinet, resulting in the resignation of the minister and the undersecretary of Finance, as well as of the minister of Economy.

Some see this episode as a turning point in the country's environmental trajectory, because environmental concerns were privileged over investment and economic growth (Madariaga, 2018). However, it could also have been rather a short-term operation, motivated by the communicational objective of building a legacy for that presidency in environmental matters. Regarding this situation, Hermann Von Mühlenbrock, the president of the business peak association Sociedad de Fomento Fabril (Federation of Chilean Industry, SOFOFA), stated that:

I have always thought that investment projects should be rejected by technical observations, but when it is done through social reflections and as those that were heard today by the authorities in charge of the vote on the Environmental Qualification Resolution, I would like to know who can explain to Chileans with few resources and with few job options, that they will remain the same and that this will remain their reality, due to the rejection of projects like Dominga that bring nothing but development to the country.

(Paleo, 2017 [translation by the authors])

The confrontation between subsector regulation and regime aspiration are thus manifest in this case. ${ }^{5}$ 


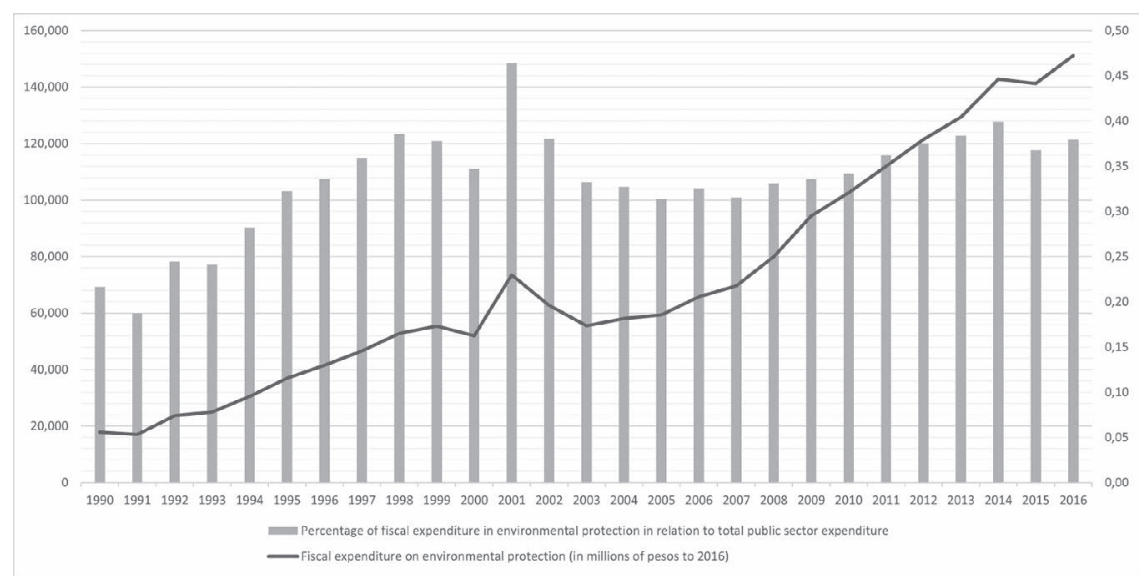

Figure 9.5 Evolution of fiscal expenditure in environmental protection (percentage and real values)

Source: Authors based on Madariaga's (2018) data

\section{Budget evidence of the weak position of environmental institutions}

As stated earlier, there is reasonable doubt that change in the environmental subsystem has been transformative. An analysis of public spending on the environment supports this argument. Madariaga (2018) has observed that public spending has increased an average of $8.3 \%$ annually since 1990 . It constitutes $2 \%$ over the average increase in the national budget. However, the argument about the increase in environmental protection spending can be nuanced, as Figure 9.5 shows.

The graph allows two readings - either enthusiastic or cautious. The positive view emphasizes the progressive increase in public spending on environmental protection from the return to democracy to the present day. On the other hand, its share of total public expenditure has remained at a low level (between $0.2 \%$ and $0.4 \%$ ). Therefore, the main findings based on the data analyzed is that the development of environmental spending in Chile has been rather marginal. This context coincides with a policy regime that has been maintained, notwithstanding important formal institutional changes that have taken place in the last decade at the subsystem level.

\section{Conclusion}

Environmental policies in Chile were formulated with a free market approach, in which the exploitation of natural resources remained ideologically and politically consolidated, keeping the environmental institutions virtually unchanged for 15 years (Tecklin et al., 2011). The institutional reforms in the 
environmental sector implemented during 2010 constitute for many a "lost opportunity" (Sepúlveda \& Villarroel, 2012). Therefore, since progress has not been seen in the legitimization and democratization of environmental decisions, socio-environmental conflicts will continue to persist (Sepúlveda \& Villarroel, 2012). In this way, it is observed that different institutional problems related to the regulation of business activity persist. The limits of citizen participation ${ }^{6}$ and the technical weaknesses of regulatory instruments are a good example of that.

Furthermore, it is possible to observe this failure not only in specific political discussions between different high-level political actors and in their intervention on projects with environmental impact, but also in areas such as social conflict, and in the increase of socio-environmental conflicts in Chile (Delamaza et al., 2017). This observation verifies the argument raised in this chapter: while changes in policy subsystems develop, global patterns that promote economic growth rather than environmental protection are nevertheless maintained as well. This is what constitutes an apparent change in the context of the policy regime as opposed to a substantive change, where clear limits to extractive activities would be set and development alternatives would be explored. Even though there has been an ecological modernization in the country, it is not transformative of the policy regime, keeping the natural resources curse as a constant feature. The new formal institutions themselves continue to reinforce the established extractive patterns and their impacts on the environment and territories. These findings confirm what some have raised as the continuity of neoliberalism in Chile (Madariaga, 2018), although this time in the environmental field.

While in Chile environmentalists may have won some battles, where the state finally withdrew support for emblematic extractive projects, they have not won the war. This trajectory can best be understood as the product of a persistent policy regime that prevails over apparent changes in the environmental subsystem. Hence, the dynamics of environmental governance must be understood in its confrontation with the deeply resilient power of a longstanding project of economic growth and a persistent extractive development regime.

\section{Notes}

1 This work was supported by National Agency for Research and Development [grant number ANID/FONDAP/15130009]; National Agency for Research and Development [grant number ANID/FONDAP/15110009]; and National Agency for Research and Development [grant number ANID/FONDECYTREGULAR/ 1180496]. Our thanks to Valentina Cariaga, Merry Hernández, Nicolás López and Francisco Martínez, all students from Public Administration at Universidad de Chile, for their valuable research assistance. Our appreciation to Bettina Schorr and Gerardo Damonte who helped us to improve the manuscript with their comments.

2 In this work, we use alternatively as synonyms the term subsystem from the discourse mostly in the United States, and the term sector from the discourse mostly in Europe.

3 Gellert has theorized the extractive regime based on the case of Indonesia (Gellert, 2010). Nem Singh and Bourgoin use it, but without an explicit definition (Nem Singh \& Bourgoin, 2013). 
4 This term was coined by environmental activists critical of Frei's stance on the environmentversus-growth dilemma, as stated by environmental leader Sara Larraín (González, 2006).

5 The final interpretation of this case requires some caution. A few weeks after the Committee of Ministers decision, the company appealed to the environmental court, which ruled that the process had to be brought back to an early stage, at the regional level, and the Supreme Court is at this time analyzing this decision.

6 In projects with environmental impact, early participation is practiced voluntarily and usually turned into an instance for negotiation. Participation is loose and focused on driving forward companies' projects rather than promoting democracy. There is little involvement of government officials in the process and little control over how well information are gathered and processed (Ocampo-Melgar et al., 2019)

\section{References}

Amengual, M. (2018). Buying stability: The distributive outcomes of private politics in the Bolivian mining industry. World Development, 104, 31-45. https://doi.org/10.1016/j. worlddev.2017.11.008

Barandiaran, J. (2016). The authority of rules in Chile's contentious environmental politics. Environmental Politics, 25(6), 1013-1033. https://doi.org/10.1080/09644016.2016.1218156

Campos-Medina, F. (2019). Ecological modernization from the actor's perspective: Spatiotemporality in the narratives about socio-ecological conflicts in Chile. Time \& Society, 28(3), 1239-1271. https://doi.org/10.1177/0961463x17752284

Campos-Medina, F., \& Larenas, J. (2012). La despolitización del conflicto socio-ecológico en la legislación medioambiental chilena a partir de los años noventa. Bitacora Urbano Territorial, 21(2), 45-56.

Carruthers, D. (2001). Environmental politics in Chile: Legacies of dictatorship and democracy. Third World Quarterly, 22(3), 343-358. https://doi.org/10.1080/01436590120061642

Carruthers, D., \& Rodríguez, P. (2009). Mapuche protest, environmental conflict and social movement linkage in Chile. Third World Quarterly, 30(4), 743-760. http://doi. org/10.1080/01436590902867193

Centro de Estudios Públicos-CEP. (2001). Estudio nacional de opinión pública. Crecimiento y medio ambiente (Documento de trabajo No. 320). CEP.

Delamaza, G., Maillet, A., \& Martínez-Neira, C. (2017). Socio-territorial conflicts in Chile: Configuration and politicization (2005-2014). European Review of Latin American and Caribbean Studies, 104, 23-46. https://doi.org/10.18352/erlacs.10173

EFE. (2013, May 30). Piñera en Canadá: Barrick tiene que cumplir reglas medioambientales en Pascua Lama. In La Segunda Online. www.lasegunda.com/Noticias/Politica/2013/05/851784/ Pinera-en-Canada-Barrick-tiene-que-cumplir-reglas-medioambientales-en-Pascua-Lama

Falleti, T., \& Riofrancos, T. (2018). Endogenous participation: Strengthening prior consultation in extractive economies. World Politics, 70(1), 86-121. https://doi.org/10.1017/ S004388711700020X

Farías, C., \& Aveggio, P. (2009, May 4). Empresa sanitaria deberá pagar $\$ 2.500$ millones de indemnización por caso La Farfana. La Tercera. www.latercera.com/noticia/empresa-sanitariadebera-pagar-2-500-millones-de-indemnizacion-por-caso-la-farfana

Frei, E. (2003, September 25). La política de medio ambiente de Chile. El País. https://elpais. com/diario/2003/09/25/sociedad/1064440806_850215.html

Gamboa, R., \& Segovia, C. (2006). Las elecciones presidenciales y parlamentarias en Chile, diciembre 2005-enero 2006. Revista de Ciencia Política (Santiago), 26(1), 84-113. https:// doi.org/10.4067/S0718-090X2006000100005 
Gellert, P. K. (2010). Extractive regimes: Toward a better understanding of Indonesian development. Rural Sociology, 75(1), 28-57. https://doi.org/10.1111/j.1549-0831.2009.00001.x

González, C. (2006, July 25). Ecologista: 'doctrina Frei’ le hace mal al país en materia ambiental. Chile Sustentable. www.chilesustentable.net/ecologista-doctrina-frei-le-hace-mal-al-paisen-materia-ambiental/

Halpern, C., \& Jacquot, S. (2015). Aux frontières de l'action publique: L'instrumentation comme logique de (dé)sectorisation. In L. Boussaguet, S. Jacquot, \& P. Ravinet (Eds.), Une "French touch" dans l'analyse des politiques publiques? (pp. 57-84). Presses de Sciences Po. https://doi.org/10.3917/scpo.bouss.2015.01

Haslam, P. A. (2016). Overcoming the resource curse: Reform and the rentier State in Chile and Argentina, 1973-2000. Development and Change, 47(5), 1146-1170. https:// doi.org/10.1111/dech.12259

Heikkila, T., Berardo, R., Weible, C. M., \& Yi, H. (2018). A comparative view of advocacy coalitions: Exploring shale development politics in the United States, Argentina, and China. Journal of Comparative Policy Analysis: Research and Practice, 21(2), 1-16. https://doi. org/10.1080/13876988.2017.1405551

Jochim, A., \& May, P. J. (2010). Beyond subsystems: Policy regimes and governance. Policy Studies Journal, 38(2), 303-327. https://doi.org/10.1111/j.1541-0072.2010.00363.x

Leiva, F. (2019). Economic elites and new strategies for extractivism in Chile. European Review of Latin American and Caribbean Studies, 108, 131-152. https://doi.org/10.32992/ erlacs.10511

Lira, J. (2017). Revisión y propuestas para el sistema de evaluación de impacto ambiental en Chile (Serie Informe Económico No. 267). Libertad y Desarrollo. https://lyd.org/wp-content/ uploads/2017/12/SIE-267-Revision-y-propuestas-para-el-Sistema-de-Evaluacion-deImpacto-Ambiental-en-Chile-Octubre17.pdf

Madariaga, A. (2016). Mechanisms of neoliberal resilience: Comparing exchange rates and industrial policy in Chile and Estonia. Socio-Economic Review, 15(3), 1-24. https://doi. org/10.1093/ser/mww015

Madariaga, A. (2018). From "green laggard" to regional leader: Explaining the recent development of environmental policy in Chile. Bulletin of Latin American Research, 38(4), 453-470. https://doi.org/10.1111/blar.12841

Mahoney, J. (2000). Path dependence in historical sociology. Theory and Society, 29(4), 507-548. www.jstor.org/stable/3108585

Mahoney, J., \& Thelen, K. (2010). A theory of gradual institutional change. In J. Mahoney \& K. Thelen (Eds.), Explaining institutional change. Ambiguity, agency and power (pp. 1-37). Cambridge University Press.

Maillet, A., \& Carrasco, S. (2019). Regulación y poder empresarial: El caso del transporte público en Santiago (2007-2017). Revista de Administraçao Publica, 53(5), 942-959. https:// doi.org/10.1590/0034-761220180079

Maillet, A., \& Rozas Bugueño, J. (2019). Hibridación de las políticas neoliberales. El caso de la reforma a la política eléctrica en Chile (2014-2016). Gestión y Política Pública, 28(1), 207-235. https://doi.org/10.29265/gypp.v28i1.546

May, P. J., \& Jochim, A. E. (2013). Policy regime perspectives: Policies and governing. Policy Studies Journal, 41(3), 426-452. https://doi.org/10.1111/psj.12024

Meyer, J. W., Frank, D. J., Hironaka, A., Schofer, E., \& Tuma, N. B. (1997). The structuring of a world environmental regime, 1870-1990. International Organization, 51(4), 623-651.

Muller, P. (2009). Sector. In L. Boussaguet, S. Jacquot, P. Ravinet, \& P. Muller (Eds.), Diccionario de políticas públicas. Universidad Externado de Colombia. 
Nem Singh, J., \& Bourgoin, F. (Eds.). (2013). Resource governance and developmental States in the Global South. Palgrave Macmillan. https://doi.org/10.1057/9781137286796

Ocampo-Melgar, A., Sagaris, L., \& Gironás, J. (2019). Experiences of voluntary early participation in environmental impact assessments in Chilean mining. Environmental Impact Assessment Review, 74, 43-53. https://doi.org/10.1016/j.eiar.2018.09.004

Orihuela, J. C. (2014). Converging divergence: The diffusion of the green State in Latin America. Studies in Comparative International Development, 49, 242-265. https://doi. org/10.1007/s12116-013-9147-6

Orihuela, J. C., \& Paredes, M. (2017). Fragmented layering: Building a green State for mining in Peru. In J. C. Orihuela, E. Dargent, M. E. Ulfe, \& M. Paredes (Eds.), Resource booms and institutional pathways (pp. 97-117). Springer International Publishing. https:// doi.org/10.1007/978-3-319-53532-6_4

Paleo,D. (2017,March 10). Lasreacciones delosempresariosentornoal rechazode Dominga. ElDía. www. diarioeldia.cl/economia/dominga/reacciones-empresarios-en-torno-rechazo-dominga

Paredes, M. (2016). The glocalization of mining conflict: Cases from Peru. The Extractive Industries and Society, 3(4), 1046-1057. https://doi.org/10.1016/j.exis.2016.08.007

Peña, K., \& Vergara, T. (2017, March 17). Hernández ante rechazo a Dominga: "Mientras más arbitrariedad, más me pone en duda seriedad del pais”. Diario Financiero. www.df.cl/noticias/ economia-y-politica/gremios-laboral/hernandez-ante-rechazo-a-dominga-mientrasmas-arbitrariedad-mas-se/2017-03-16/195321.html

Pierson, P. (2004). Politics in time. History, institutions, and social analysis. Princeton University Press.

Pierson, P. (2015). Power and path dependence. In J. Mahoney \& K. Thelen (Eds.), Advances in comparative-historical analysis (pp. 123-144). Cambridge University Press.

Risley, A. (2015). Civil society organizations, advocacy, and policy making in Latin American democracies: Pathways to participation. Palgrave Macmillan. https://doi.org/10.1057/9781137502063

Schaeffer, C. (2017). Democratizing the flows of democracy: Patagonia sin represas in the awakening of Chile's civil society. In S. Donoso \& M. von Bülow (Eds.), Social movements in Chile: Organization, trajectories, and political consequences (pp. 131-160). Palgrave Macmillan. https://doi.org/10.1057/978-1-137-60013-4

Sepúlveda, C. (2000). El proyecto Celulosa Valdivia: La legitimidad del sistema de evaluación de impacto ambiental puesta en juego. In F. Sabatini, C. Sepúlveda, \& H. Blanco (Eds.), Participación ciudadana para enfrentar conflictos ambientales. Desafíos para el sistema de evaluación de impacto ambiental (pp. 23-57). Centro de Investigación y Planificación del Medio Ambiente, CIPMA.

Sepúlveda, C., \& Rojas, A. (2010). Conflictos ambientales y reforma ambiental en Chile: Una oportunidad desaprovechada de aprendizaje institucional sobre participación ciudadana. Revista Ambiente y Desarrollo, 24(2), 15-23.

Sepúlveda, C., \& Villarroel, P. (2012). Swans, conflicts, and resonance: Local movements and the reform of Chilean environmental Institutions. Latin American pespectives, 39(4), 181-200. https://doi.org/10.1177/0094582x12441519

Silva, E. (1996). Democracy, market economics, and environmental policy in Chile. Journal of Interamerican Studies and World Affairs, 38(4), 1-33. https://doi.org/10.2307/166257

Silva, E. (2016). Patagonia, without dams! Lessons of a David vs. Goliath campaign. The Extractive Industries and Society, 3(4), 947-957. https://doi.org/10.1016/J.EXIS.2016.10.004

Silva, E. (2018). Mega-Projects, contentious politics, and institutional and policy change: Chile, 1994-2017. European Review of Latin American and Caribbean Studies, 106, 139-162. http://doi.org/10.32992/erlacs.10391 
Spalding, R. J. (2018). From the streets to the chamber: Social movements and the mining ban in El Salvador. European Review of Latin American and Caribbean Studies, 106, 49-79. https://doi.org/10.32992/erlacs.10377

Streeck, W., \& Thelen, K. (2005). Beyond continuity: Institutional change in advanced political economies. Oxford University Press. ISBN: 978-0-19-928046-9

Tecklin, D., Bauer, C., \& Prieto, M. (2011). Making environmental law for the market: The emergence, character, and implications of Chile's environmental regime. Environmental Politics, 20(6), 879-898. https://doi.org/10.1080/09644016.2011.617172

World Bank Group. (2019). Region profile of Latin America and Caribbean: Doing business 2019. World Bank. www.doingbusiness.org/content/dam/doingBusiness/media/Profiles/ Regional/DB2019/LAC.pdf 